\title{
Soil Resources Study in Dumbrăvești Area - Prahova County, to Seize Their Best for Agricultural Use
}

\author{
Mariana BURCEA ${ }^{1}$, Marian MUSAT ${ }^{1}$, Daniela CRETU $^{1}$, Andrei IOVA ${ }^{1}$ \\ ${ }^{1}$ University of Agricultural Sciences and Veterinary Medicine, Bucharest, 59 Marasti, District 1, 011464, \\ Bucharest, Romania; \\ * corresponding author: dr_marianmusat@yahoo.com
}

Bulletin USAMV series Agriculture 72(1)/2015

Print ISSN 1843-5246; Electronic ISSN 1843-5386

DOI 10.15835/buasvmcn-agr: 11181

\begin{abstract}
The study area is located at the confluence of Vărbilău with Teleajen, a former mansion previously having multiple uses (garden, orchard, pasture), with an empirical adjustment, but effective, now decommissioned, into fallow or degraded pasture.There have been a sleeper in the lower part of the territory (the Vărbilău's alluvial) to the set, in the highest part. Due to varied topography, and other factors which conditioned pedogenetical, resulting many types and subtypes of soils classified in several classes: Protisols (Fluvisols), Luvisols (Luvisols) and Anthrosols (Erodosols).This paper presents the physico-chemical and morphological properties of soils, their analytical data and evaluation opportunities for best uses, particularly orchards.
\end{abstract}

Keywords: agricultural use, edaphic resources, soil evaluation, soil taxonomy.

\section{INTRODUCTION}

The study area lies at the confluence of the river Vărbilău with Teleajen, a former mansion previously having multiple uses (garden, orchard, pasture), with an empirical but effective regulation currently disused, into fallow or degraded pasture. There have been a sleeper in the lower part of the territory (the alluvial Vărbilău) wedge plate in the highest.

Due to varied topography, and other factors which conditioned pedogenetical, resulting many types and subtypes of soils classified in several classes: protisols (aluviosols), luvisols (luvosols) and anthrisols (erodosols) (Musat et al., 2013).

This paper presents the physico-chemical and morphological properties of soils, their analytical data and evaluation opportunities for best uses, particularly orchards.

\section{MATERIAL AND METHOD}

The study area belongs to the DumbrăveștiPrahova village, both in urban and terrain, the plans provided by the beneficiary, images onsite and Google (Satellite), (Fig. 1).

The foundation geology is very complex because amid geosyncline accumulated sediments that have undergone various processes of metamorphism. Crystalline basement was peneplenization is intense and represented the fossil relief phase. Peneplenization phases fall in the scale of the area at different depths morphostructural but separate in all cases (Borlan and Hera, 1973).

The study area falls within the perimeter of neogen sinclinal, subject to subsidence movements Pleistocene and Holocene wedge, being heavily faulted.

Evolution of Teleajen to teh Cricovul Sărat Salty was performed under the influence of storage processes characteristic dynamics dejection cones covered with alluvial deposits-proluvial. These deposits consist of an alternation of sands, loams and clays of Quaternary origin forming fluvial deposits that have evolved soils. 
Main form of relief in which the study area it is plain, and is located at the confluence of PrahovaTeleajen dejection cones. It consists of several steps piedmont (coastal terraces with precolinar glacies aspect, having altitudes between 150-160 m, with digression transition to low plain fragmented by intense torrential valleys).

The natural vegetation is typical of steppe and forest steppe, which was replaced by orchards and natural grasslands are predominant association of Agrostis tenuis and local vegetation islands xerophylous, hydrophilic, and sands. So prevalent hydrophilic species are rush (Phragmites Communis), sedge (Carex Limosa), mint (Mentha Aquatica), horsetail (Equisetum Palustre) etc. Also, on the sands appear barley wild (Elymus Sabulosus), rust (Juncus Maritima), sand wormwood (Arthemisia Arenaria), sand sedge ( $C$. Colchina) etc.

Besides herbaceous species mentioned above occur and some shrubs represented by: Salix Cinerea, Cornus Sanguinea, Rosa Canina, Prunus Sp., Hyppophae Rhamnoides etc. or trees of the genera: Populus, Salix Alba, Quercus etc.

Quaternary deposits are the most important „covering” for groundwater. Vertical distribution of these layers and their degree of permeability affects the groundwater dynamics.

Besides herbaceous species mentioned above occur and some shrubs represented by: Salix Cinerea, Cornus Sanguinea, Rosa Canina, Prunus Sp., Hyppophae Rhamnoides etc. or trees of the genera: Populus, Salix Alba, Quercus etc. Quaternary deposits are "covering" the most important groundwater. Vertical distribution of

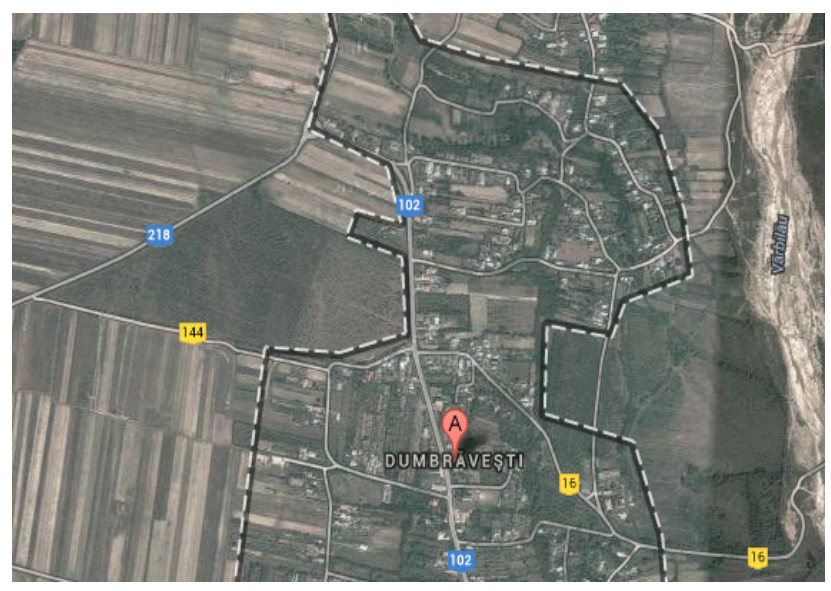

Fig. 1. Overview of the studied area these layers and their degree of permeability affects the groundwater dynamics.

Piedmont plain in the falling studied area is characterized by great depths over $10 \mathrm{~m}$ in the higher perimeter peri hilly and variable values 3-5 $\mathrm{m}$ or $5-10 \mathrm{~m}$ in the floodplain and in the transition to the divagation.

Their presence is closely related to geological factors, stratigraphy, lithology, topography and climate, which in turn can be permanent (geological structure, texture, mineralogical composition of deposits and landforms) temporary or permanent change and influence the quality of these deposits (amount of water, groundwater level, the water chemistry, etc.).

They present both groundwater at shallow depth, because relief is predominantly floodplain, located less than $2 \mathrm{~m}$ in places, and surface water (stagnant), which creates problems in the land use. Teleajen River, with a length of $122 \mathrm{~km}$, has a tortuosity factor of 1.54 with an average slope of $13 \%$. For the most part, the course is relatively straight, weak meander, with 19 main tributaries. The annual average flow is $1.24 \mathrm{~m}^{3} \mathrm{~s}^{-1}$, and in dry periods, it could fall below $0.8 \mathrm{~m}^{3} \mathrm{~s}^{-1}$, (Fig. 2).

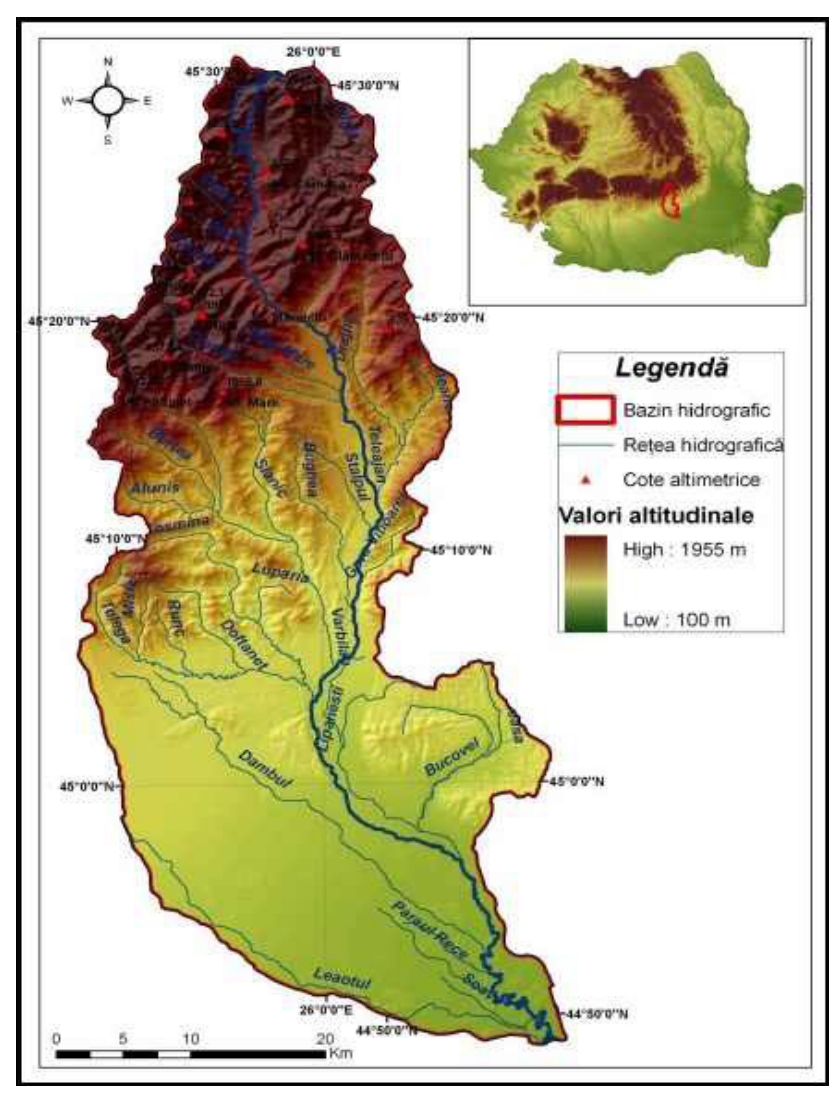

Fig. 2. Basin Teleajen 
The general climate of the area is continental, characterized by high thermal amplitude, low temperatures in winter, due to penetration of Arctic air masses, and high temperatures in summer, due to penetration of tropical air masses.

The studied territory, falling from climatic transition from semi-dry to the wet area. Average annual rainfall are between $650-660 \mathrm{~mm}$, annual average temperatures is $9^{\circ} \mathrm{C}$ and the aridity index (And) 30-35 (Mușat and Radu, 2007).

The annual rainfall average that enters into soil is partially retained by the solid soil and available to plants in the form of water easily accessible, with direct influence on production.

Soils identified in the investigated area are fully consistent with the lithology, topography, climate and vegetation of the area. Thus, the identified soil type, will be displayed the morphological and physical / chemical in the order in which the samples were collected (Tab. 1).

\section{RESULTS AND DISCUSSIONS}

In soils formed in alluvial area of Vărbilău (meadow), the percentage of sand has values of 50.3 to $58 \%$, and the clay content varies between 9.8 and $26 \%$. In soils formed on the plateau and on the terraces, the clay content is between 30 and $44 \%$ while the percentage of fine sand varies between 26.4 and $40.9 \%$.

Soil reaction is moderately acid-weak character on the terrace and plateau soils and in the floodplain soil reaction has values of 6.9 to 8.0 (neutral to slightly alkaline).
Humus content is small and very small on terrace and plateau and on pastures is maintained as medium due to intense accumulation processes, formats over time. All types of land are formed in the meadow have strong effervescence on the surface opposed to the soils on flat land and plate, where the carbonate occurs in more than $150 \mathrm{~cm}$ into the depth (Lacatusu, 2006).

Physical properties of these soils confirmed the above, giving high levels of the bulk density and low values for total porosity.

\section{CONCLUSIONS}

Restoration of drainage ditches by clogging the channels and outlets already traced and profiled.

Application of organic fertilizers (especially) in order to filling the chemical content needed for crop nutrients, regardless of land use.

Making absorbent wells on land where water Băltești (apple orchard, D7) as visible spots redox to form specific stagnogleyzation horizons.

Making ripping works, especially in gravel (D2 and D3), the removal of coarse fragments (rocks, boulders) in order to improve the effectiveness of soil edaphic volume.

Clearing current plantations (apple or plum) which are in prolonged downturn.

Desiccant herbicide products based gliphosat (Roundup, Gliphogan etc.).

Making sloppy work $(60-80 \mathrm{~cm})$ if it is intended reestablishment plantations.

Planting in orchards native species with deep root system (apple, plum) and superficial (cherry).

Tab. 1. Analytical data of soil profiles (0-20 cm depth) - Dumbrăvești area - Prahova county

\begin{tabular}{ccccccccccc}
\hline $\begin{array}{c}\text { Soil } \\
\text { type }\end{array}$ & $\begin{array}{c}\text { Corse } \\
\text { sand }\end{array}$ & $\begin{array}{c}\text { Fine } \\
\text { sand }\end{array}$ & Silt & Clay & Soil reaction $\mathrm{pH}$ & $\mathrm{Humus}$ & $\mathrm{CaCO}_{3}$ & $\begin{array}{c}\text { Bulk } \\
\text { density }\end{array}$ & $\begin{array}{c}\text { Total } \\
\text { Porosity }\end{array}$ & $\begin{array}{c}\text { Land } \\
\text { use }\end{array}$ \\
\hline ASka & 16.8 & 58.0 & 15.4 & 9.8 & 7.6 & 2.8 & eferv. & 1.63 & 38 & pasture \\
\hline ASpr & 14.0 & 58.0 & 7.0 & 21.0 & 8.0 & 5.8 & eferv & 1.56 & 48 & pasture \\
\hline ASka & 12.2 & 54.1 & 9.8 & 23.9 & 6.9 & 2.9 & eferv. & 1.58 & 41 & pasture \\
\hline ASka & 1.4 & 53.8 & 8.4 & 26.4 & 6.9 & 2.9 & eferv. & 1.52 & 42 & $\begin{array}{c}\text { apple } \\
\text { tree }\end{array}$ \\
\hline ASka & 21.1 & 50.3 & 13.2 & 24.4 & 7.4 & 3.0 & eferv. & 1.56 & 43 & $\begin{array}{c}\text { apple } \\
\text { tree }\end{array}$ \\
\hline LVti & 14.6 & 37.5 & 18.2 & 29.7 & 5.1 & 3.2 & 0 & 1.52 & 47 & pasture \\
\hline ASpr & 13.7 & 56 & 8.5 & 21.8 & 7.8 & 5.6 & eferv. & 1.55 & 48 & $\begin{array}{c}\text { apple } \\
\text { tree }\end{array}$ \\
\hline LVab & 5.9 & 26.4 & 24.1 & 43.6 & 4.9 & 1.4 & 0 & 1.49 & 44 & $\begin{array}{c}\text { plume } \\
\text { tree }\end{array}$ \\
\hline LVab & 18.3 & 40.9 & 25.2 & 15.6 & 4.7 & 1.2 & 0 & 1.53 & 47 & $\begin{array}{c}\text { plume } \\
\text { tree }\end{array}$ \\
\hline
\end{tabular}




\section{REFERENCES}

1. Borlan Z, Hera C (1973). Metode de apreciere a stării de fertilitate a solurilor în vederea folosirii raționale a îngrăşămintelor. Editura Ceres, București.

2. Lăcătuşu R (2006). Agrochimie. Ediția a II-a, Editura Terra Nostra, Iaşi.

3. Mușat M, Radu A (2007). Geologie și geomorfologie. Ed. Printech, București.
4. Mușat M, Radu A, Burcea M (2013). Pedoagrotehnică. Ed. Ceres, București;

5. ***(1987). Metodologia Elaborării Studiilor Pedologice Partea III, Indicatori Ecopedologici, București.

6. ${ }^{* * *}$ (1997). Ordinul 756/1997 al MAPPM

7. ***(2012). Sistemul Roman de Taxonomie a Solurilor (SRTS). Ed. Sitech, Craiova. 